\title{
Screening of Antagonistic Bacteria from Endophytes against Walnut Blight Pathogen Xanthomonas arboricola pv. juglandis
}

\author{
Benzhong Fu* (D), Lei Yu, Bokai Wang and Cao Zheng \\ Hubei Key Laboratory of Quality Control of Characteristic Fruits and Vegetables, \\ College of Life Science and Technology, Hubei Engineering University, Hubei Xiaogan 432000, China.
}

\begin{abstract}
Walnut blight caused by Xanthomonas arboricola pv. juglandis (Xaj) is the most important bacterial disease in walnut production worldwide. To seek biocontrol agents against Xaj, we screened 152 endophytic bacteria isolated from 87 plants. Through dual-culture method screening, we obtained four antagonistic bacteria, ATE17, BME17, CIE17, and OFE17 which were isolated from Amaranthus tricolor, Bambusa multiplex, Canna indica, and Osmanthus fragrans plants respectively. The inhibition ratios of ATE18, BME17, CIE18, and OFE17 against Xaj on plates were 1.5, 1.6, 1.3, and 1.6, respectively. These indicated they have good biocontrol potential for walnut bacterial blight. Subsequently, the four endophytic bacteria were identified by morphology, Gram staining, Microbial Identification System (fatty acid methyl ester analysis), as well as $16 \mathrm{~S}$ rDNA and gyrB sequencing. It turns out that all four strains were identified as Bacillus sp. Furthermore, the two strains BME17 and OFE17 can suppress multiple plant fungal pathogens and bacterial pathogens on plates.

Keywords: Antagonism, Bacillus sp., Bambusa multiplex, Biocontrol agent, Endophytic bacteria, Osmanthus fragrans
\end{abstract}

*Correspondence: benzhongf@yahoo.com; zhengc1314@163.com

(Received: April 11, 2021; accepted: June 24, 2021)

Citation: Fu B, Yu L, Wang B, Zheng C. Screening of Antagonistic Bacteria from Endophytes against Walnut Blight Pathogen Xanthomonas arboricola pv. juglandis. J Pure Appl Microbiol. 2021;15(3):1384-1392. doi: 10.22207/JPAM.15.3.30

(C) The Author(s) 2021. Open Access. This article is distributed under the terms of the Creative Commons Attribution 4.0 International License which permits unrestricted use, sharing, distribution, and reproduction in any medium, provided you give appropriate credit to the original author(s) and the source, provide a link to the Creative Commons license, and indicate if changes were made. 


\section{INTRODUCTION}

English walnut or Persian walnut (Juglans regia $\mathrm{L}$ ) belongs to the Juglandaceae family Juglans genus. It is an important edible nut, wood oil crop, and valuable timber tree species ${ }^{1}$. Walnut kernels are composed largely of polyunsaturated fatty acid, alpha-linolenic acid, which gives them antiatherogenic properties and brain health benefits. Walnut oil may even serve as a helpful natural remedy for hyperlipidemic patients with type 2 diabetes ${ }^{2}$. So walnuts have both nutritional and medicinal benefits ${ }^{3}$. Walnuts are widely spread both natively and commercially in Europe, Asia, and part of the United States ${ }^{4}$.

Walnut planting areas have increased sharply over the past several decades, particularly in Asia. In 2018, the global walnut harvest area was 1159484 ha with production 3662507 tonnes. China alone has harvested an area of 390224 ha with production 1586367 tonnes $^{5}$. The harvest area and production of China accounting for $33.65 \%$ and $43.31 \%$, respectively of global totals. With the walnut planting area increasing substantially, walnut bacterial blight caused by Xanthomonas arboricola pv. juglandis (Xaj) is also spreading around the world ${ }^{6,7}$. Currently, the disease is the most important bacterial disease affecting walnut production. The disease has sparked international concern and has been added to $C A B I$ (Centre for Agriculture and Bioscience International) invasive species list ${ }^{8}$. Walnut bacterial blight negatively affects almost all walnut crown tissues. It causes early defoliation, fruit blackening and decay, immature dropping, kernel drying, oil and yield reducing, then serious walnut productivity losing and quality decreasing ${ }^{9}$.

The management of walnut bacterial blight has to date mainly relied on chemical pesticides such as copper-based compounds and streptomycin-dominated antibiotics ${ }^{10,11}$. However, these conventional control agents are now recognized to produce adverse residue and environmental problems, as well as having decreased effectiveness due to emerging pesticide resistance $\mathrm{e}^{10,12,13}$.

Using biological control methods based on microbes or their derivatives has become an important direction in plant disease control. Among them, the use of plant endophytes has more advantages compared to other microorganisms in plant disease control, therefore it is one of the current hot spots in biological control research $14,15,16,17$. Endophytes are facultative or obligate symbiotic microorganisms that live in apparently healthy internal plant tissues, without causing disease ${ }^{17}$. Endophytes have a capacity for disease prevention, as well as plant growth promotion, aid nitrogen fixation, and are beneficial to host plant development ${ }^{18,19,20}$.

There are many research reports on the screening, identification, and utilization of plant endophytes in plant disease control. For instance, there are fungal endophytes for suppression of Rhizoctonia solani ${ }^{21}$. Wheat endophytes inhibit the growth of Fusarium head blight. Fusarium graminearum inhibition of $30-51 \%$ and Fusarium culmorum inhibition of $15-53 \%$ have been established by dual culture assays in vitro ${ }^{22}$. Soybean endophytic bacteria Bacillus sp. and Burkholderia sp. have been proved that they can control bacterial and fungal pathogens of the host effectively in vitro, such as Sclerotinia sclerotiorum, Phomopsis sojae, and Rhizoctonia solani $^{23}$. Dogwood (Cornus florida) endophyte A22F1 has high potential as a biological control agent for Phytophthora capsici in pepper ${ }^{24}$. Some endophytes have been translated into commercial products $^{14}$.

The identification of novel biocontrol agents is a critical step in the development of commercial biocontrol products ${ }^{25}$. Some attempts have been made in walnut bacterial blight biocontrol agent exploration. These include the examination of medicinal plant essential oils and aqueous extracts ${ }^{26}$ and bacteriophages isolated from walnut orchard soils in New Zealand and Chile ${ }^{27,28,29}$. Screening, identification, and evaluation for antagonistic bacteria led to four Pseudomonas fluorescens strains being identified as putative antagonists of $X a j$ and being shown to significantly reduce symptoms on walnut leaves $(41 \% \text { to } 82 \%)^{30}$.

To search for more potential biocontrol agent candidates from plant endophytes resources, we investigated 50 families and 86 species of plants to isolate and screen their antagonistic effects on Xaj in vitro. Through conventional and modern techniques, we identified four antagonistic 
Table 1. Two endophytes against different plant pathogens on plates

\begin{tabular}{lccc}
\hline Diseases & Pathogens & OFE17 & BME17 \\
\hline Wheat Fusarium Head Blight & Fusarium graminearum & 0.63 & 0.55 \\
Orchid black spot & Alternaria alternata & 0.72 & 0.65 \\
Walnut anthracnose & Gloeosporium fructigenum. & 0.63 & 0.67 \\
Maca root rot & F. avenaceum. & 0.51 & 0.53 \\
Camellia black spot & A. alternate & 0.61 & 0.48 \\
Citrus scab & Sphaceloma fawcettii & 0.30 & 0.33 \\
Corn ear rot & F. graminearum & 0.76 & 0.78 \\
Gray leaf spot of corn & Cercospora sorghi & 0.66 & 0.68 \\
Corn northern leaf blight & Setosphaeria turcica & 0.52 & 0.67 \\
Rice blast & Magnaporthe grisea & 0.73 & 0.74 \\
Rice bacterial leaf streak & Xanthomonas oryzae pv. oryzae & 2.45 & 1.21 \\
Rice bacterial blight & X. oryzae pv. oryzicola & 1.86 & 2.18 \\
\hline
\end{tabular}

Note: The values for fungal pathogens mean suppression ratio; for bacterial pathogens means $D / d$ ratio. Each value represents the mean of three replicates.

endophytes with great potential biocontrol capacity against Xaj from four different plant species.

\section{MATERIALS AND METHODS}

\section{Plants and target pathogen strains}

Ninety-four samples from various parts and tissues of healthy plants were collected from Xiaogan city, Hubei province from May to September in 2017. They are distributed across 50 families, 84 genera, and 86 species (Supplement Table 1). Screening target pathogen strain Xaj BW $3 \mathrm{~F}^{31}$ was isolated in 2015 from Baokang county, Hubei province, and maintained on YPGA (Yeast powder $5 \mathrm{~g}$, peptone $5 \mathrm{~g}$, D-glucose $10 \mathrm{~g}$, deionized water $1000 \mathrm{~mL}$, agar $15 \mathrm{~g}, \mathrm{pH} 7.2)^{32}$ and storage at $-80^{\circ} \mathrm{C}$ in $30 \%$ glycerol. More plant fungal and bacterial pathogens for antagonistic spectrum tests are listed in Table 1.

Isolation of plant endophytes

Plant samples were washed with tap water and sterilized water three times. They were then cut into around $1 \mathrm{~cm}^{2}$ patch, surface disinfected in $75 \%$ ethanol for $3 \mathrm{~min}$ then in $0.1 \% \mathrm{HgCl}_{2}$ for $1 \mathrm{~min}$. These were mashed up and suspended in $\mathrm{dd}_{2} \mathrm{O}$. The tissue debris suspension was spread onto a selective medium plate based on YPGA supplement with Cephalexin $(30 \mu \mathrm{g} / \mathrm{L})$ and Cycloheximide $(100 \mu \mathrm{g} / \mathrm{L})^{33}$, incubated at $28^{\circ} \mathrm{C}$ for 2 days. Endophytes were picked for purification and cultured on a YPGA plate at $28^{\circ} \mathrm{C}$.

\section{Screening of antagonistic bacteria}

The antagonistic effect was tested via the dual culture method ${ }^{34}$. In short, fresh endophyte suspension $5 \mu \mathrm{l}\left(\mathrm{OD}_{600}=0.5\right)$ inoculate to the center of the plate spread with $200 \mu \mathrm{l}$ Xaj DW3F3 $\left(\mathrm{OD}_{600}=0.5\right)$. After incubating for $2-3 \mathrm{~d}$ at $28^{\circ} \mathrm{C}$, the inhibitory zone and endophyte colony size are measured. Inoculation of $\mathrm{ddH}_{2} \mathrm{O}(2 \mu \mathrm{l})$ and Kanamycin $(50 \mu \mathrm{g} / \mathrm{mL})(2 \mu \mathrm{l})$ as the negative and positive control, respectively. The inhibitory rate $(D / d)$ is calculated by dividing the inhibitory zone diameter $(\mathrm{D}, \mathrm{mm})$ by the endophyte colony diameter $(\mathrm{d}, \mathrm{mm})$. Each treatment was conducted

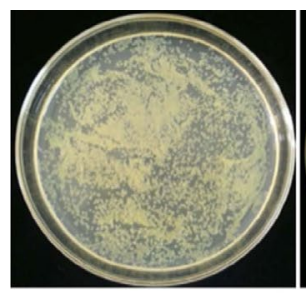

Negative control

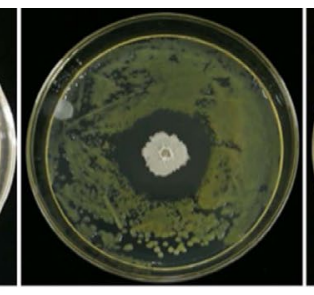

ATE17-Xaj

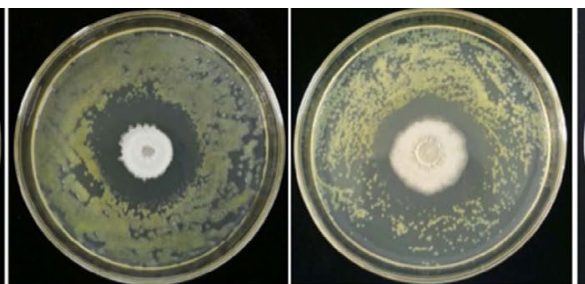

BME17-Xaj
CIE17-Xaj

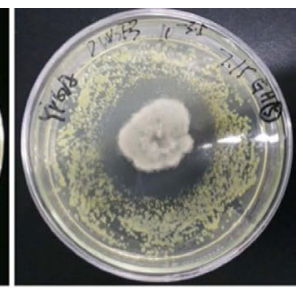

OFE17-Xaj

Fig. 1. Antagonistic effects of four endophytes against Xaj DW3F3 on YPGA plates. 
Table 2. Endophytic bacteria identification by microbial identification system based on Fatty Acid Analysis (MIDI)

\begin{tabular}{lcccl}
\hline $\begin{array}{l}\text { Antagonistic } \\
\text { bacteria }\end{array}$ & $\begin{array}{c}\text { Entry } \\
\text { Name }\end{array}$ & $\begin{array}{c}\text { Percent } \\
\text { Named }\end{array}$ & $\begin{array}{c}\text { Sim } \\
\text { Index }\end{array}$ & Library \\
\hline ATE17 & Bacillus subtilis & $91.70 \%$ & 0.583 & RTSBA6 6.21 \\
BME17 & Bacillus subtilis & $94.14 \%$ & 0.777 & RTSBA6 6.21 \\
CIE17 & Bacillus subtilis & $93.52 \%$ & 0.77 & RTSBA6 6.21 \\
OFE17 & Bacillus subtilis & $93.31 \%$ & 0.756 & RTSBA6 6.21 \\
\hline
\end{tabular}

in triplicate with three plates. Those endophytes with obvious inhibitory zones on plates were stocked in $30 \%$ glycerol at $-80^{\circ} \mathrm{C}$.

\section{Identification of antagonistic bacteria}

Four strains with strong antagonistic effects against Xaj DW3F3 on YPGA plates were chosen to identify. They were denoted as ATE17 (Amaranthus tricolor endophyte isolated in 2017), BME17 (Bambusa multiplex endophyte isolated in 2017), CIE17 (Canna indica endophyte isolated in 2017), and OFE17 (Osmanthus fragrans endophyte isolated in 2017).

The cellular morphology of these strains was observed by Gram staining. The strains were then subjected to identification by the Microbial Identification System (MIDI Inc) based on Fatty Acid Methyl Ester (FAME) profiles. Bacterial genomic DNA was then extracted using EZ-10 Spin Column Bacterial Genomic DNA Mini-Preps Kit (Sangon Biotech Shanghai Co., Ltd.) for subsequent molecular identification. The PCR procedure and two sets of primers were used, 16S rDNA 27 F?5'-AGAGTTTGATCCTGGCTCAG-3' and 1492R?5'GGTTACCTTGTTACGACTT-3', and gyrB UP-1:

\section{5'-GAAGTCATCATGACCGTTCTGCAYGCNGGNGGN} AARTTYGA-3' and UP-2:5'-AGCAGGGTACGG ATGTGCGAGCCRTCNACRTCNGCRTCNGTCAT-3' sequences came from Bavykin et $\mathrm{al}^{35}$. The $16 \mathrm{~S}$ rDNA and gyrB amplicons were sequenced by Sangon Biotech (Shanghai) Co., Ltd. Then the sequences were subjected to phylogenetic tree construction using the MEGAX software ${ }^{36}$.

Test of BME17 and OFE17 against multiple plant pathogens

To assay the potential ability of the endophytes against other plant pathogens, we selected two endophytes BME17 and OFE17 which showed a high inhibition ability isolated from two different plants. We tested the antagonistic effects of the two endophytes on 10 different plant fungal pathogens and two bacterial pathogens collected in our laboratory. The method used was the same as described above except the fungal confrontation culture was carried out on PDA plates. The suppression effect on fungal pathogens was calculated by (negative control radius-treat radius)/negative control radius (radius in $\mathrm{mm}$ ).

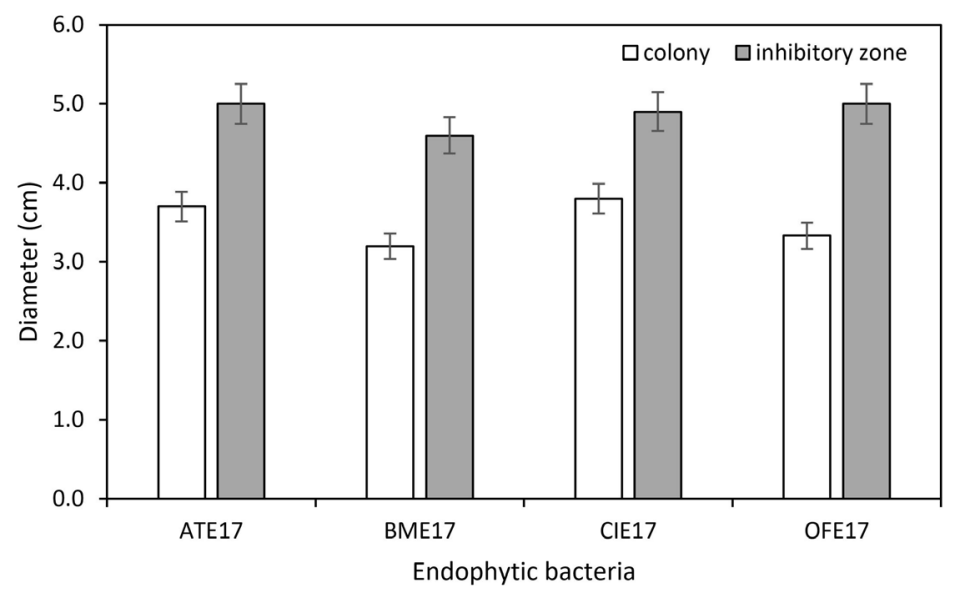

Fig. 2. Inhibitory zone size of four endophytes against Xaj DW3F3 on YPGA plates. 


\section{RESULTS}

Obtained four potential biocontrol agent endophytes

One hundred fifty-two endophytic bacterial strains were isolated and purified from 86 species of plants. Through dual culture screening of the target pathogen Xaj DW3F3 one by one, four strains with significant antagonistic effects on Xaj DW3F3 were obtained and verified more than five times (Fig.1). The inhibition ratio (D/d) of four endophytes ATE17, BME17, CIE17, and OFE17 were 1.5, 1.6, 1.3, and 1.6, respectively (Fig.2).

Morphology and fatty acid identification

After being cultured on YPGA plates for 24 to $48 \mathrm{~h}$, four antagonist strain colonies were nearly round, light white, or slightly yellow. Taking a fresh colony to Gram staining and observing it under a microscope (Nikon ECLIPSE Ni-U), the cells are rod-shaped and the Gram stain is positive.

The microbial identification system based on fatty acid is fully automated for bacterial identification. It showed that the strains ATE17, BME17, CIE17, and OFE17 were most similar to
Bacillus subtilis in the software's library database (Table 2).

\section{S rRNA and gyrB molecular identification}

The 16S rDNA partial sequences of four antagonist strains ATE17, BME17, CIE17, and OFE17 were run through the Blastn against the NCBI Standard databases ( $\mathrm{nr}$, etc.) Nucleotide collection (nr/nt). These four strains are judged to be similar to dozens of different Bacillus sp., with query coverage $100 \%$, E value 0.0 , and percentage identity $100 \%$. A phylogenetic tree was constructed based on 17 Bacillus species and one out group species Virgibacillus halodenitrificans through the Neighbor-Join algorithm (bootstrap $=500$ ) (Fig. 3). Their classification position cannot be inferred yet on this basis.

The gyrB partial sequences of four antagonist strains ATE17, BME17, CIE17, and OFE17 were sequenced. These sequences were subjected to an NCBI Blastn search as above. They are judged to be highly similar to many different Bacillus sp. with query coverage $100 \%$, E value 0.0 , and percentage identity $100 \%$ as well. $A$

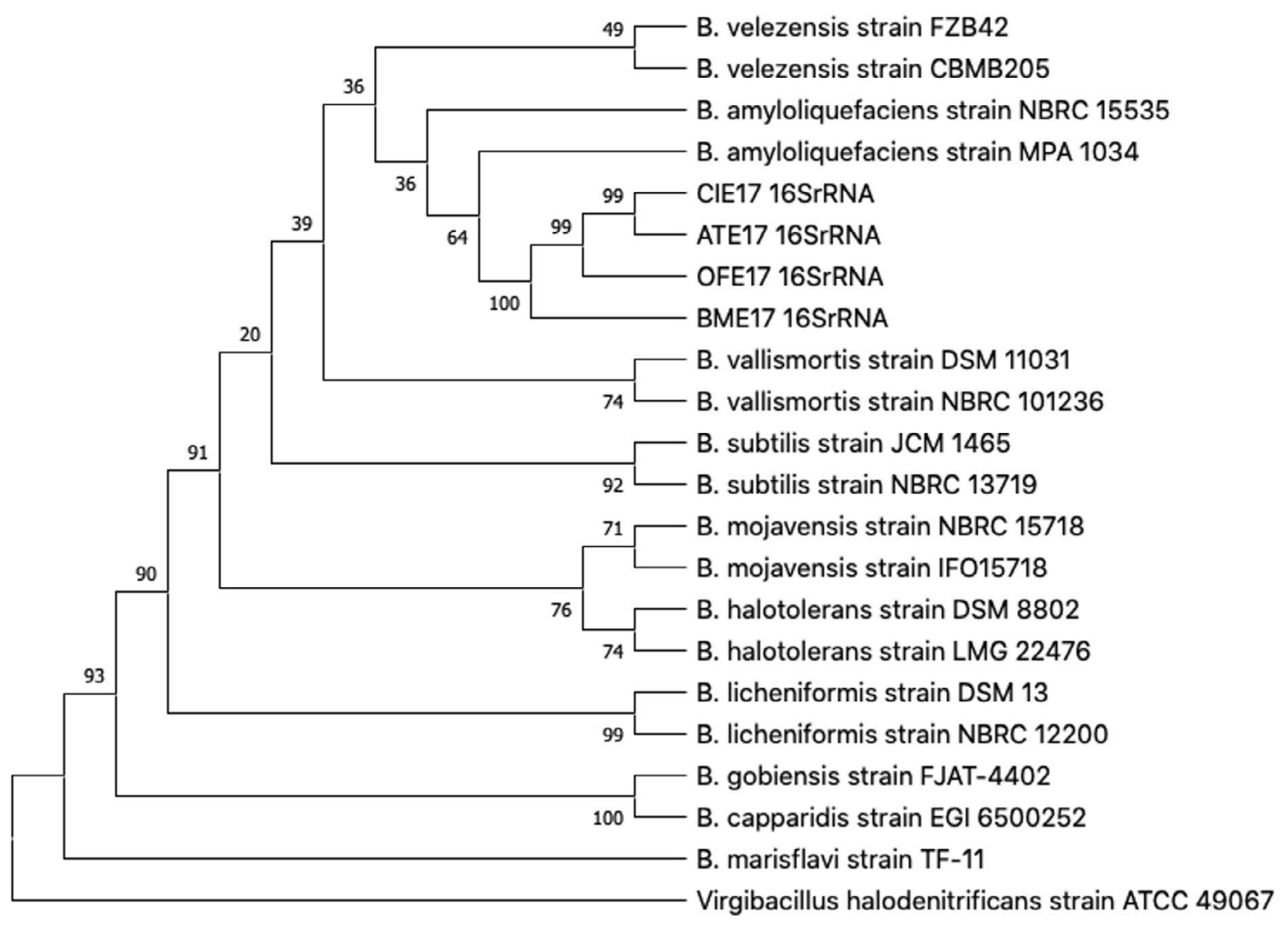

Fig. 3. Phylogenetic tree based on Neighbor-joining tree of 22 16S-rRNA gene partial sequences. 
phylogenetic tree was constructed based on highly similar sequences with more than $98 \%$ identity and $98 \%$ query coverage (bootstrap $=1000$ ) (Fig. 4). Based on the tree, we cannot infer species positions for these strains.

Hereby, we tentatively identified the four antagonist bacteria as Bacillus sp. based on combined morphology, microbe identification system, and housekeeping genes.

\section{Inhibition of different pathogens by BME17 and} OFE17

We selected the two endophytes BME17 and OFE17 for assessing their antagonistic properties against various plant pathogens. The two endophytes presented antagonistic effects on all 10 crop fungal pathogens and two rice bacterial pathogens (Table 1). The result suggests the strains have broad-spectrum antagonistic roles instead of specific functions and have potential biocontrol roles against both fungal and bacterial diseases.

\section{DISCUSSION}

Developing novel, economical, and environment-friendly walnut bacterial blight biocontrol agents is challenging. Amongst, exploiting plant endophytes is an important methodology in this direction.

Screening biocontrol agents from many plant resources is the first step in this important work. However, to date, only a few plant endophytes have been screened for the treatment of disease. Ozaktan et al ${ }^{30}$ assayed 29 epiphytes from healthy walnut leaves against Xaj, 18 strains have antagonistic effects with inhibitory zone 3.0 to $13.0 \mathrm{~mm}$. Bacteria measured as around $60 \%$ antagonistic, have decreased walnut bacterial blight $41-77 \%$ on walnut seedlings.

In this study, we screened 152 endophytes from 86 plant species, and obtained four strains with strong antagonistic effects on the target pathogen Xaj. Through multiple identification

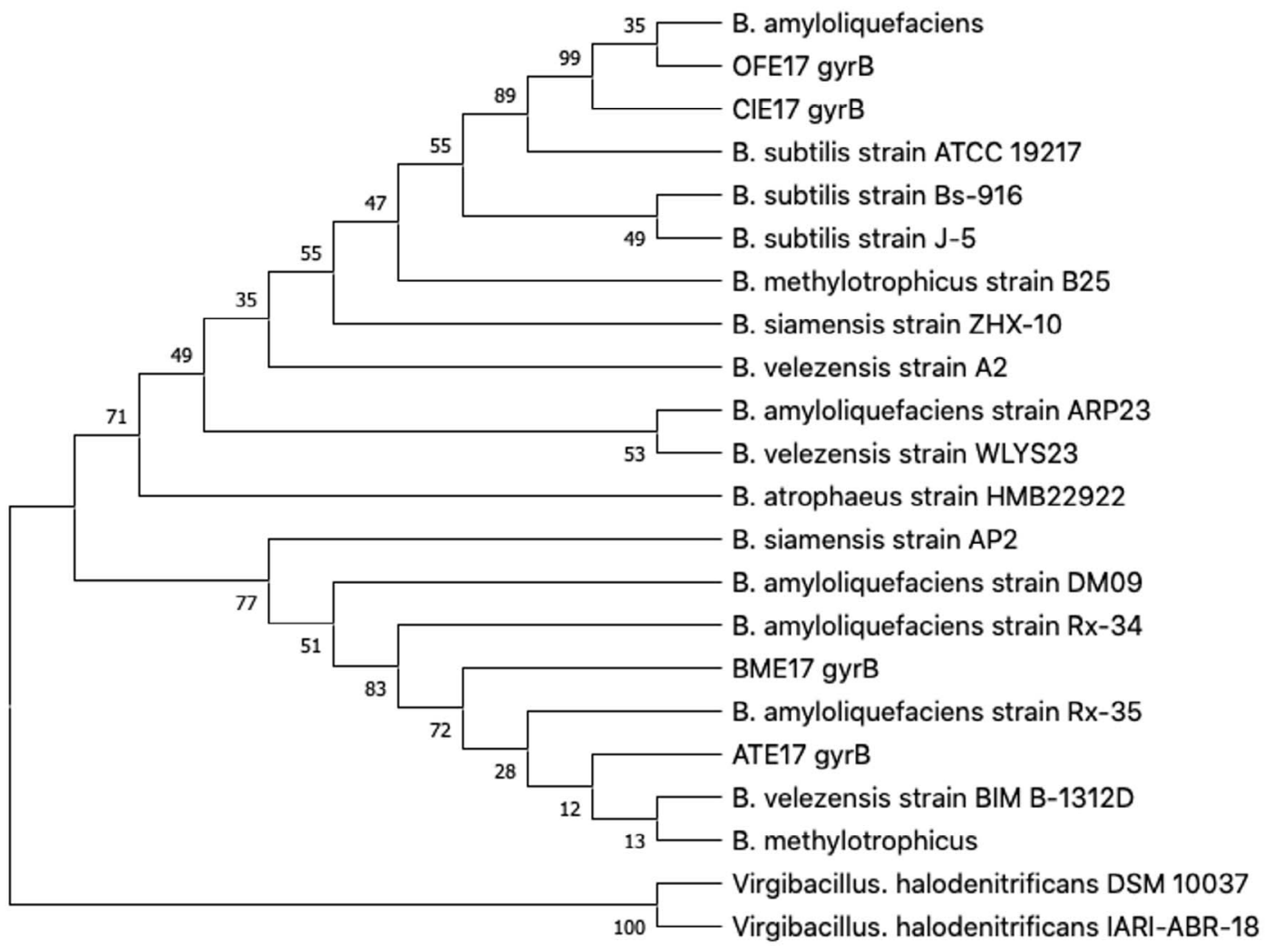


methods, we determined that they are all Bacillus sp. (this identification is tentative, due to Bacillus genera classification complexity). These antagonistic bacteria do not belong to the same genera as those identified as $P$. fluorescens against $X a j^{30}$. The in vitro inhibition provides the first evidence that these endophytes are potential biocontrol agents of walnut bacterial blight. Our research has added to the potential arsenal of a biological agent in combating walnut bacterial blight.

Although we screened 152 endophytes, only four potential biocontrol agent strains were discovered (their effects verified through experimental replication). The positive selection frequency is $2.6 \%$. This low frequency is similar to that found in research in coffee berry disease antagonistic bacteria screening, in which from a total of 4323 microorganisms isolates around 3\% exhibited detectable inhibition ${ }^{37}$.

We obtained antagonistic bacteria isolated from four plants common in our location, A. tricolor, B. multiplex, C. indica, and O. fragrans. In each of these plants, only some endophytes were studied for their biocontrol ability. For example, there were 46 endophytic bacteria and 17 fungi isolated from amaranth plant, among them six bacterial endophyte isolates and one fungal endophyte were found to be efficient in inhibiting the growth of its leaf blight pathogen Rhizoctonia solani in vitro ${ }^{38}$. Endophytic fungi isolates from bamboo (Phyllostachys edulis) branches were found to have high bioactivity against Botryotinia fuckeliana and Thanatephorus cucumeris ${ }^{39}$. Endophytic bacteria were isolated from $C$. indica proved to be P.fluorescens, Enterobacter sp., Erwinia sp. and all of them have plant growth promoting ability ${ }^{40}$. There were two endophytes isolated from 0 . fragrance that were identified as Bacillus sp. too. One endophyte Bacillus sp. isolated from $O$. fragrance can be used in honey wine $^{41}$. Another endophyte strain B. safensis B21, isolated from $O$. fragrans fruits, showed antifungal activity against Magnaporthe oryzae $e^{42}$. These are thus broad antimicrobe spectrum bacteria we tested in this study. These Bacillus spp. are not only antagonistic against bacteria but also fungi.

In our search process, we only isolated 152 endophytic bacteria from 86 plant species. On one hand, we added antibiotics into the isolation medium and on the other hand, the bacterial colony was hard to distinguish. We simply picked up those distinct single colonies obvious to the naked eye. Possibly we ignored some isolates on the plates with similar colony morphology.

Bacillus bacteria is one of the most important biocontrol resources. Many active substances have been discovered, and even already used in the field. In our projects, the evaluation of biocontrol effectiveness on plants, and active substances are under investigation. Although we obtained four potential antagonistic bacteria, there is much additional work to be done on the way to developing powerful biocontrol agents for disease control. The present results will lay a foundation for further exploring the function and application of such agents in the future.

\section{SUPPLEMENTARY INFORMATION}

Supplementary information accompanies this article at https://doi.org/10.22207/JPAM.15.3.30

Additional file: Additional Table S1.

\section{ACKNOWLEDGMENTS}

We would like to thank Dr. Stephen B. Vardeman from lowa State University for his meticulous language editing of this manuscript.

\section{CONFLICT OF INTEREST}

The authors declare that there is no conflict of interest.

\section{AUTHORS' CONTRIBUTION}

BF designed the experiments. $L Y$ and $B W$ performed the experiments. $B F, L Y$ and $B W$ analyzed the data. BF wrote the manuscript. $\mathrm{CZ}$ reviewed and edited the manuscript. All authors read and approved the manuscript.

\section{FUNDING}

This work was supported by the National Natural Science Foundation of China (31700069).

\section{DATA AVAILABILITY}

The sequences obtained during this study are included in the manuscript with a public database deposit number. 


\section{ETHICS STATEMENT}

This article does not contain any studies with human participants or animals performed by any of the authors.

\section{REFERENCES}

1. Pollegioni $P$, Woeste $K$, Chiocchini $F$, et al. Rethinking the history of common walnut (Juglans regia L.) in Europe: Its origins and human interactions. PLOS One. 2017;12(3):e0172541. doi: 10.1371/journal. pone.0172541

2. Zibaeenezhad MJ, Farhadi P, Attar A, et al. Effects of walnut oil on lipid profiles in hyperlipidemic type 2 diabetic patients: A randomized, double-blind, placebocontrolled trial. Nutr Diabetes. 2017;7:e259. doi:10.1038/ nutd.2017.8

3. Ros E, Izquierdo-Pulido M, Sala-Vila A. Beneficial effects of walnut consumption on human health: Role of micronutrients. Curr Opin Clin Nutr Metab Care. 2018;21(6):498-504. doi: 10.1097/ MCO.0000000000000508

4. Bernard A, Lheureux F, Dirlewanger E. Walnut: past and future of genetic improvement. Tree Genet Genomes. 2018;14:1. doi: 10.1007/s11295-017-1214-0

5. http://www.fao.org/faostat/en/\#data/QC/visualize.

6. Frutos D. Bacterial diseases of walnut and hazelnut and genetic resources. Journal of Plant Pathology. 2010;92:S1.79-s1.85.

7. Lamichhane JR. Xanthomonas arboricola Diseases of Stone Fruit, Almond, and Walnut Trees: Progress Toward Understanding and Management. Plant Disease. 2014;98(12):1600-1610. doi: 10.1094/PDIS-08-14-0831FE

8. https://www.cabi.org/isc/datasheet/56946.

9. Moragrega C, Matias J, Aletà N, Montesinos E, Rovira M. Apical Necrosis and Premature Drop of Persian (English) Walnut Fruit Caused by Xanthomonas arboricola pv. juglandis. Plant Disease. 2011;95(12):1565-1570. doi:10.1094/PDIS-03-11-0259

10. Ninot A, Aletà N, Moragrega $\mathrm{C}$, Montesions E. Evaluaton of a reduced copper spraying program to control bacterial blight of walnut. Plant Disease. 2002;86(6):583-587. doi:10.1094/PDIS.2002.86.6.583

11. Polito VS, Pinney K, Buchner R, Olson W. Streptomycin applications to control walnut blight disease can prevent fertilization and increase fruit drop. HortScience. 2002;37(6):940-942. doi: 10.21273/HORTSCI.37.6.940

12. Gardan L, Brault T, Germain E. Copper resistance of Xanthomonas capestris pv. juglandis in French walnut orchards and its association with conjugative plasmids. Acta Hortic. 1993;311:259-265. doi: 10.17660/ ActaHortc.1993.311.33

13. Vagelas LK, Rumbos $\mathrm{Cl}$, Tsiantos J. Variation in disease development among persian walnut cultivars, selections and crosses when inoculated with Xanthomonas arboricola pv. juglandis in Greece. Journal of Plant Pathology. 2012;94:S1.57-S1.61.

14. Mota MS, Gomes CB, Souza Junior IT, Moura AB. Bacterial selecton for biological control of plant disease: criterion determination and validation. Braz J Microbiol. 2017;48(1):62-70. doi: 10.1016/j.bjm.2016.09.003
15. Parikh L, Eskelson MJ, Adesemoye AO. Relationship of in vitro and in planta screening: improving the selection process for biological control agents against Fusarium root rot in row crops. Archives of Phytopathology and Plant Protection. 2018;51(3-4):156-169. doi: 10.1080/03235408.2018.1441098

16. De Silva NI, Brooks S, Lumyong S, Hyde KD. Use of endophytes as biocontrol agents. Fungal Biol Rev. 2019;33(2):133-148. doi: 10.1016/j.fr.2018.10.001

17. Rabiey M, Hailey LE, Roy SR, et al. Endophytes vs tree pathogens and pests: can they be used as biological control agents to improve tree health? Eur J Plant Pathol. 2019;155:711-729. doi: 10.1007/s10658-019-01814-y

18. Alström S, Van Vuurde JWL. Endophytic Bacteria and Biocontrol of Plant Diseases. Plant Pathogenic Bacteria. 2001:60-67. doi: 10.1007/978-94-010-0003-1_11

19. da Silva Ribeiro A, Polonio JC, Costa AT, et al. Bioprospection of Culturable Endophytic Fungi Associated with the Ornamental Plant Pachystachys lutea. Curr Microbiol. 2018;75(5):588-596. doi: 10.1007/s00284-017-1421-9

20. Pandey SS, Singh S, Pandey $\mathrm{H}$, et al. Endophytes of Withania somnifera modulate in planta content and the site of withanolide biosynthesis. Sci Rep. 2018;8:5450. doi: 10.1038/s41598-018-23716-5

21. Lahlali R, Hijri M. Screening, identification and evaluation of potential biocontrol fungal endophytes against Rhizoctonia solani AG3 on potato plants. FEMS Microbiol Lett. 2010;311(2):152-159. doi:10.1111/j.15746968.2010.02084.x

22. Comby $M$, Gacoin $M$, Robineau $M$, et al. Screening of wheat endophytes as biological control agents against Fusarium head blight using two different in vitro tests. Microbiol Res. 2017;202:11-20. doi: 10.1016/j. micres.2017.04.014

23. de Almeida Lopes KB, Carpentieri-Pipolo V, Fira D, et al. Screening of bacterial endophytes as potential biocontrol agents against soybean diseases. J Appl Microbiol. 2018;125(5):1466-1481. doi: 10.1111/jam.14041

24. Mmbaga MT, Gurung S, Maheshwari A. Screening of Plant Endophytes as Biological Control Agents against Root Rot Pathogens of Pepper (Capsicum annum L.). J Plant Pathol Microbiol. 2018;9(3):435. doi:10.4172/21577471.1000435

25. Raymaekers K, Ponet L, Holtappels D, Berckmans B, Cammue BPA. Screening for novel biocontrol agents applicable in plant disease management - A review. Biological Control. 2020;144:104240. doi: 10.1016/j. biocontrol.2020.104240

26. Soltani J, Aliabadi AA. Antibacterial Effects of Several Plant Extracts and Essential Oils on Xanthomonas arboricola pv. juglandis in vitro. Journal of Essential Oil Bearing Plants. 2013;16(4):461-468. doi:10.1080/09720 60X.2013.813246

27. McNeil DL, Romero S, Kandula J, Stark C, Stewart A, Larsen S. Bacteriophages a potential biocontrol agent against walnut blight (Xanthomonas campestris pv juglandis). New Zealand Plant Protecton. 2001;54:220224. doi:10.30843/nzpp.2001.54.3743

28. Romero-Suarez S, Jordan B, Heinemann JA. Isolation and characterization of bacteriophages infecting Xanthomonas arboricola pv. juglandis, the causal agent of walnut blight disease. World J Microbiol Biotechnol. 
2012;28(5):1917-1927. doi: 10.1007/s11274-011-0992-z

29. Retamales J, Vasquez I, Santos L, et al. Complete Genome Sequences of Lytic Bacteriophages of Xanthomonas arboricola pv. juglandis. Genome Announc. 2016;4(3):e00336-16. doi: 10.1128/genomeA.00336-16.

30. Ozaktan H, Erdal M, Akkopru A, Aslan E. Biological control of bacterial blight of walnut by antagonistic bacteria. Journal of Plant Pathology. 2012;94(1):S1.53-S1.56.

31. Fu B, Chen $\mathrm{Q}$, Wei $\mathrm{M}$, et al. Complete genome sequence of Xanthomonas arboricola pv. juglandis strain DW3F3, isolated from a Juglans regia L. bacterial blighted fruitlet. Genome Announc. 2018;6(8):e00023-18. doi: 10.1128/ genomeA.00023-18

32. Hajri $A$, Meyer $D$, Delort F, Guillaumès J, Brin C, Manceau $C$. Identificaton of a genetic lineage within Xanthomonas arboricola pv. juglandis as the causal agent of vertical oozing canker of Persian (English) walnut in France. Plant Pathol. 2010;59(6):1014-1022. doi: 10.1111/j.13653059.2010.02362.x

33. Palacio-Bielsa A, Pothier JF, Perez MR, Duffy B, Lopez $M M$. Detection and identification methods and new tests as developed and used in the framework of cost873 for bacteria pathogenic to stone fruits and nuts: Tumorigenic agrobacterium spp. Journal of Plant Pathology. 2012;94(1):97-104.

34. Lin Y, Du D, Si C, Zhao Q, Li Z, Li P. Potential biocontrol Bacillus sp. strains isolated by an improved method from vinegar waste compost exhibit antibiosis against fungal pathogens and promote growth of cucumbers. Biological Control. 2014;71:7-15. doi: 10.1016/j. biocontrol.2013.12.010

35. Bavykin SG, Lysov YP, Zakhariev V et al. Use of $16 \mathrm{~S}$ rRNA, $23 \mathrm{~S}$ rRNA, and gyrB gene sequence analysis to determine phylogenetic relationships of Bacillus cereus group microorganisms. J Clin Microbiol. 2004;42(8):3711-3730. doi: 10.1128/JCM.42.8.3711-3730.2004

36. Kumar S, Stecher G, Li M, Knyaz C, Tamura K. MEGA $\mathrm{X}$ : Molecular Evolutionary Genetics Analysis across Computing Platforms. Mol Biol Evol. 2018;35(6):15471549. doi: $10.1093 / \mathrm{molbev} / \mathrm{msy} 096$

37. Asfaw K, Husein T, Ayalew A, Dejene M, Sahile S. In vitro Screening and Characterizing the Most Promising Antagonistic Microorganism as Biocontrol Agent(s) Against Colletotrichum kahawae. European Journal of Experimental Biology. 2018;8(1):1. doi: 10.21767/22489215.100042

38. Uppala SS, Beena S, Chapala MM, Bowen KL. Amaranth endophytes and their role in plant growth promotion. In: Reddy MS, Desai S, Sayyed RZ, et al (Ed.). Plant Growth Promotion by Rhizobacteria for Sustainable Agriculture. India: Scientific Publishers. 2010:531-537.

39. Shen X, Zheng D, Gao J, Hou C. Isolation and evaluation of endophytic fungi with antimicrobial ability from Phyllostachys edulis. Bangladesh Journal of Pharmacology. 2012;7(4):249-257. doi: 10.3329/bjp.v7i4.12068

40. Wang $X$, Zhang $M$, Yan $P$, et al. Growth promoting ability and enhanced effects on water purification of endophytic bacteria from Canna indica. Journal of Lake Sciences. 2019;31:1582-1591.

41. Fan J, He R, Wu H, et al. Study on the Screening of Osmanthus fragranse Endophytes and the Technology Condition for Making Honey Wine. Heilongjiang Agricultural Sciences. 2015,10:149-151.

42. Rong $\mathrm{S}, \mathrm{Xu} \mathrm{H}, \mathrm{Li} \mathrm{L}, \mathrm{Chen} \mathrm{R}, \mathrm{Gao} \mathrm{X}, \mathrm{Xu} \mathrm{Z}$. Antifungal activity of endophytic Bacillus safensis B21 and its potential application as a biopesticide to control rice blast. Pestic Biochem Physiol. 2020;162:69-77. doi: 10.1016/j. pestbp.2019.09.003 